\title{
AKTIVITAS ANTIVIRUS BEBERAPA EKSTRAK TANAMAN TERHADAP BEAN COMMON MOSAIC VIRUS STRAIN BLACK EYE COWPEA (BCMV-BIC) PADA KACANG PANJANG
}

\author{
Tri Asmira Damayanti \& Martha Theresia Panjaitan \\ Departemen Proteksi Tanaman, Fakultas Pertanian, Institut Pertanian Bogor \\ Jl. Kamper, Kampus IPB Dramaga, Bogor 16680 \\ E-mail: triasmiradamayanti@gmail.com
}

\begin{abstract}
Antivirus actitivity of several plant extracts against Bean common mosaic virus strain Black eye cowpea (BCMV-BlC) on Yard long bean. Bean common mosaic virus (BCMV) is an important virus on yard long bean and it is difficult to control. One of control effort way by utilizing antiviral substances of plant origin. The research was done to select and test the effectiveness of plant extracts in suppressing BCMV infection on yard long bean. Twenty two plant extracts were selected by (1) spraying the crude extract to Chenopodium amaranticolor leaves, then plant inoculated by BCMV 1 hour after spraying, and (2) mixturing the crude extract with sap containing BCMV, then inoculated mechanically to C. amaranticolor. Local necrotic lesion number and inhibition percentage are measured. All plant extract treatments were able to reduce Necrotic lokal lesion formation significantly compared to untreatment control. Further, fifteen plant extracts were selected to test their effectiveness in controlling BCMV on yard long bean in green house trial. The results showed that except geranium and red ginger treatment, other extract treatments were able to reduce significantly the disease incidence and severity, symptoms, and BCMV titer, respectively. Among tested extracts, Bougainvillea spectabilis, Mirabilis jalapa, and Celosia cristata are the most effective crude extracts in suppressing BCMV infection.
\end{abstract}

Key words: antiviral, bean common mosaic virus, plant extract, yard long bean

\section{ABSTRAK}

\begin{abstract}
Aktivitas antivirus beberapa ekstrak tanaman terhadap bean common mosaic virus strain black eye cowpea (bcmv-blc) pada kacang panjang. Bean common mosaic virus (BCMV) merupakan virus yang penting pada tanaman kacang panjang dan diketahui sulit dikendalikan. Salah satu upaya pengendalian yang layak untuk dikaji adalah pemanfaatan substansi antivirus asal tanaman. Penelitian ini bertujuan menyeleksi dan menguji ekstrak tanaman yang bersifat antivirus dalam mengendalikan infeksi BCMV di rumah kaca. Ekstrak tanaman potensial diseleksi dari 22 spesies tanaman, dengan cara (1) penyemprotan ekstrak kasar ke tanaman indikator Chenopodium amaranticolor kemudian diinokulasi BCMV 1 jam setelah penyemprotan, dan (2) mencampur ekstrak kasar dengan sap yang mengandung BCMV, kemudian diinokulasi ke tanaman $C$. amaranticolor. Peubah pengamatan terdiri dari jumlah lesio lokal nekrotik (LLN) dan persentase penghambatan LLN. Semua perlakuan ekstrak tanaman mampu menghambat pembentukan LLN secara nyata dibandingkan dengan kontrol. Efikasi 15 ekstrak tanaman menunjukkan bahwa kecuali ekstrak geranium dan jahe merah, perlakuan ekstrak tanaman lainnya mampu mereduksi kejadian penyakit, keparahan penyakit, gejala, dan titer BCMV. Diantara ekstrak yang diuji, ekstrak daun bogenvil, pukul empat, dan jengger ayam merupakan ekstrak yang paling efektif menekan BCMV pada kacang panjang.
\end{abstract}

Kata kunci: antivirus, bean common mosaic virus, ekstrak tanaman, kacang panjang

\section{PENDAHULUAN}

Produktivitas kacang panjang di Indonesia cenderung mengalami fluktuasi dari tahun ke tahun (BPS, 2012). Udayashankar et al. (2010) menyatakan bahwa penyakit virus memberikan kontribusi yang besar terhadap penurunan produksi kacang panjang terutama di daerah Asia, Amerika Latin, dan Afrika. Salah satu upaya untuk mengendalikan virus adalah dengan pemanfaatan substansi antivirus dari ekstrak tanaman yang dilaporkan mampu mengendalikan beberapa virus karena mengandung ribosome inactivating proteins (RIPs) (Verma et al., 1998) dan juga merupakan salah satu agen yang dapat menginduksi ketahanan sistemik suatu tanaman (Rusak et al., 1997; Deephti et al., 2007). Beberapa ekstrak tanaman seperti daun pukul empat, jengger ayam, dan daun patah tulang pernah dilaporkan efektif mengendalikan Tobacco mosaic virus (TMV), 
Tomato mosaic virus (ToMV), Tomato spotted wilt virus (TSWV), Potato virus Y (PVY), dan Potato spindle tuber viroid (PSTVd) (Kubo et al., 1990; Balasaraswathi et al., 1998; Vivanco et al., 1999; Balasubrahmanyam et al., 2000; Rajesh et al., 2005; Mahdy et al., 2010; Madhusudhan et al., 2011). Daun pagoda dan daun pukul empat dilaporkan efektif mengendalikan Cucumber mosaic virus (CMV) pada cabai (Hersanti, 2004), virus gemini pada cabai (Duriat, 2008) dan ekstrak kasar yang dibuat dengan air juga dilaporkan mampu menekan BCMV di rumah kaca dengan aplikasi semprot (Kurnianingsih \& Damayanti, 2012).

Pada tahun 2008-2009 terjadi ledakan penyakit mosaik kuning pada tanaman kacang panjang yang meluas di beberapa daerah di Jawa Barat dan Jawa Tengah. Salah satunya disebabkan oleh BCMV strain Black eye cowpea (BCMV-BlC) (Damayanti et al., 2009). Upaya yang dianjurkan untuk mengatasi penyakit tumbuhan adalah menggunakan varietas tahan atau toleran jika tersedia. Beberapa kultivar komersial yang ada saat ini dilaporkan rentan terhadap infeksi BCMV (Setyastuti, 2008; Susetio, 2011), sehingga sampai saat ini BCMV belum teratasi di lapangan. Oleh karena itu perlu dikaji upaya pengendalian lain yang dapat dieksplorasi seperti pemanfaatan ekstrak tanaman. Indonesia memiliki kekayaan plasma nutfah tumbuhan yang melimpah. Namun, di Indonesia belum banyak informasi terkait ekstrak-ekstrak tanaman yang berpotensi sebagai antivirus terhadap BCMV atau terhadap virus-virus lainnya. Oleh karena itu tujuan dari penelitian ini ialah menyeleksi dan menguji potensi antivirus asal tanaman hias dan herbal untuk mengendalikan BCMV pada kacang panjang.

\section{METODE PENELITIAN}

Tempat dan Waktu. Penelitian ini dilaksanakan di Laboratorium Virologi Tumbuhan dan rumah kaca Cikabayan, Dramaga, Bogor dari bulan Januari sampai Juni 2013.

Perbanyakan Inokulum. Isolat BCMV strain Black eye cowpea (BCMV-BlC) diperoleh dari koleksi Laboratorium Virologi Tumbuhan, Departemen Proteksi Tanaman. Sumber inokulum diperbanyak dengan menginokulasikan secara mekanis kacang panjang kultivar Parade berumur 7 hari setelah tanaman (HST) dengan cairan tanaman sakit (sap). Inokulum digerus menggunakan mortar dan pistil steril bersama bufer fosfat $\mathrm{pH} 7.2$ yang mengandung $1 \% \beta$-mercaptoethanol (ditambahkan sebelum digunakan), dengan perbandingan inokulum dan bufer adalah 1:10 (b/v). Inokulum yang terdapat pada mortar dipersiapkan di atas es. Daun pertama kacang panjang sehat ditaburi carborundum 600 mesh, lalu sap diinokulasi secara mekanis. Setelah diinokulasi daun dibilas dengan akuades dan dipelihara sampai tanaman bergejala. Sebagai sumber inokulum digunakan daun muda yang bergejala.

Pembuatan Ekstrak Tanaman. Ekstrak kasar dibuat berdasarkan protokol yang dikemukakan oleh Deepthi et al. (2007) dengan modifikasi minor, yaitu rasio bahan tanaman dan bufer 1:5 (b/v) dan tanpa sonikasi. Ekstrak kasar dibuat dari $10 \mathrm{~g}$ bahan tanaman (daun/ kulit buah/ rimpang) yang digerus dengan mortar dan pistil dalam $50 \mathrm{ml} \mathrm{0,01} \mathrm{M} \mathrm{bufer} \mathrm{fosfat} \mathrm{pH} 7,2$. Ekstrak kemudian disaring dengan kain kasa dan disentrifugasi pada kecepatan $10.000 \mathrm{rpm}$ selama 10 menit. Supernatan yang didapat digunakan untuk pengujian.

\section{Seleksi Ekstrak Tanaman Potensial pada} Chenopodium amaranticolor. Seleksi ekstrak tanaman potensial dilakukan pada tanaman indikator C. amaranticolor umur 2 bulan yang diberi perlakuan ekstrak tumbuhan dan diinokulasi dengan BCMV. Ekstrak kasar yang diseleksi adalah termasuk (1) tanaman hias yaitu anyelir (Dianthus caryophyllus), daun bogenvil (Bougenvillia spectabilis), daun cemara kipas (Thuja orientalis), daun geranium (Pelargonium odoranthisimum), daun jengger ayam (Celosia cristata), daun pagoda (Clerodendrum paniculatum), daun patah tulang (Euphorbia tirucalli), daun pukul empat (Mirabilis jalapa) dan (2) tanaman herbal yaitu rimpang jahe merah (Zingiber officinale), daun jambu biji (Psidium guajava), daun kecubung (Datura stramonium), rimpang kunyit (Curcuma domestica), rimpang kunyit putih (Curcuma manga), kulit manggis (Garcinia mangostana), daun meniran (Phylanthus niruri), daun mimba (Azadirachta indica), daun mrico kepyar (Phytollacca sp.), daun pegagan (Cantella asiatica), daun sambiloto (Andrographis paniculata), daun sirsak (Annona muricata), rimpang temulawak (Curcuma xanthorizzha), dan daun tempuyung (Sonchus arvensis).

Pada tahap seleksi untuk mendapatkan ekstrak tanaman yang potensial dilakukan dengan 2 metode. Metode (1) untuk mengetahui apakah ekstrak tanaman mampu menginduksi ketahanan sistemik, ekstrak kasar disemprotkan ke tanaman indikator $C$. amaranticolor, 1 jam kemudian diinokulasi mekanis dengan BCMV dan metode (2) untuk mengetahui apakah ekstrak tanaman 
mengandung bahan yang bersifat antivirus, ekstrak kasar dicampur dengan sap yang mengandung BCMV dengan perbandingan 1:1, kemudian diinokulasi bersamaan ke tanaman C. amaranticolor. Tanaman kontrol sakit tidak diberi perlakuan ekstrak tanaman, tetapi hanya diinokulasi dengan BCMV. Tanaman kontrol sehat tidak diberi perlakuan apapun. Setiap perlakuan terdiri dari 5 daun sebagai ulangan.

Penanaman Tanaman Uji. Tanaman uji yang digunakan adalah kacang panjang kultivar Parade. Kacang panjang ditanam pada media tanam tanah dan pupuk kandang dengan perbandingan 2:1 di dalam polybag. Tanaman uji dipelihara di rumah kaca.

Efikasi Ekstrak Potensial. Sebanyak 15 ekstrak tanaman dipilih berdasarkan seleksi awal yaitu ekstrak tanaman yang menunjukkan jumlah LLN terendah pada perlakuan pencampuran sap. Tanaman kontrol sakit tidak diberi perlakuan ekstrak tanaman, tetapi hanya diinokulasi dengan BCMV. Tanaman kontrol sehat tidak diberi perlakuan apapun. Tiap perlakuan ekstrak diuji pada 15 tanaman kacang panjang sebagai ulangan. Ekstrak tanaman dicampur dengan sap tanaman sakit dengan perbandingan 1:1, kemudian diinokulasi mekanis ke tanaman kacang panjang umur 7 hari setelah tanam (HST).

Deteksi BCMV Secara Serologi. Deteksi virus dilakukan pada 4 MSI dengan metode serologi ELISA tidak langsung (indirect-ELISA) dengan menggunakan antiserum BCMV sesuai dengan protokol yang dibuat oleh produsen antiserum (Agdia). Hasil ELISA dianalisis secara kuantitatif dengan ELISA reader pada panjang gelombang $405 \mathrm{~nm}$. Sampel dinyatakan positif jika nilai absorbansi ELISA (NAE) sampel uji 2 kali lebih besar daripada NAE kontrol negatif ELISA (tanaman sehat).

Peubah Pengamatan. Peubah pengamatan yang diamati adalah sebagai berikut:

\section{a. Peubah pengamatan seleksi ekstrak tanaman pada $C$. amaranticolor, yaitu:}

1. Jumlah lesio lokal nekrotik (LLN) yang muncul setelah perlakuan pada 10 hari setelah inokulasi (HSI)

2. Tingkat Hambatan Relatif (THR) lesio lokal nekrotik:

$$
\mathrm{THR}=\frac{(\mathrm{K}-\mathrm{P})}{\mathrm{K}} \times 100 \%
$$

dengan:

THR = tingkat hambatan relatif,

$\mathrm{K}=$ jumlah lesio lokal nekrotik pada kontrol, dan

$\mathrm{P} \quad=$ jumlah lesio lokal nekrotik yang diberi perlakuan.

b. Peubah pengamatan pada efikasi ekstrak tanaman dalam menekan BCMV dirumah kaca, yaitu:

1. Persentase kejadian penyakit (KP) dihitung dengan rumus:

$$
\mathrm{KP}=\frac{\text { Jumlah tanaman terinfeksi }}{\text { Jumlah tamaman diinokulasi }} \times 100 \%
$$

2. Keparahan penyakit diamati pada 4 minggu setelah inokulasi (MSI) BCMV. Kategori skor yang digunakan, yaitu skor 0 (tidak bergejala), skor 1 (gejala mosaik ringan), skor 2 (gejala mosaik sedang), skor 3 (gejala mosaik berat), skor 4 (gejala mosaik berat dengan malformasi daun yang parah, kerdil, atau mati) (Gambar 1).

3. Periode inkubasi virus dihitung sejak virus diinokulasi hingga munculnya gejala pada tanaman

4. Pengamatan jenis gejala yang muncul setelah perlakuan

5. Titer virus dalam tanaman kacang panjang ditentukan berdasarkan NAE

6. Tingkat Hambatan Relatif (THR) virus dihitung dengan rumus:

dengan:

$$
\text { THR virus }=\frac{\mathrm{A}-\mathrm{B}}{\mathrm{A}} \times 100 \%
$$

$\mathrm{A}=$ NAE kontrol terinfeksi BCMV dan

$\mathrm{B}=\mathrm{NAE}$ perlakuan

Analisis Data. Pada tahap seleksi terdiri dari 23 perlakuan (22 perlakuan ekstrak tanaman, 1 kontrol tanpa perlakuan) diuji pada 5 daun C. amaranticolor sebagai ulangan untuk tiap perlakuan ekstrak tanaman. Pada uji efikasi perlakuan terdiri dari 17 perlakuan (15 perlakuan ekstrak tanaman, kontrol sehat, dan kontrol tanpa ekstrak tanaman diinokulasi BCMV). Tiap perlakuan ekstrak diuji pada 15 tanaman kacang panjang sebagai ulangan. Rancangan percobaan yang digunakan adalah rancangan acak lengkap (RAL). Data yang diperoleh dianalisis menggunakan analisis ragam (ANOVA) menggunakan program Microsoft Office Excel 2007 dan SPSS versi 17.0 (Statistical Package for Social Sciences, USA). Pengaruh perlakuan yang berbeda nyata dilakukan uji lanjut dengan uji selang berganda Duncan (DMRT) pada taraf nyata 5\%. 


\section{HASIL DAN PEMBAHASAN}

Lesio Lokal Nekrotik (LLN). Secara umum semua perlakuan semprot ekstrak tanaman menunjukkan LLN yang nyata lebih sedikit dibandingkankan dengan kontrol tanpa perlakuan yang diinokulasi BCMV. Perlakuan semprot ekstrak daun pukul empat bahkan tidak menunjukkan LLN. THR LLN yang ditunjukkan oleh perlakuan semprot dari yang terendah (mrico kepyar) sampai tertinggi (pukul empat) berkisar 27,3-100\% (Tabel 1).

Pada perlakuan pencampuran sap dengan ekstrak tanaman juga menunjukkan jumlah lesio lokal nekrotik yang nyata lebih sedikit dibandingkan dengan kontrol tanpa perlakuan yang diinokulasi BCMV, kecuali perlakuan ekstrak patah tulang, meniran, kunyit putih, pegagan, sambiloto dan sirsak. THR LLN yang ditunjukkan oleh perlakuan pencampuran dari yang terendah (patah tulang) sampai tertinggi (pukul empat) berkisar 8,2-97,4\% (Tabel 1).

Ekstrak tanaman yang mampu menghambat pembentukan LLN hanya pada perlakuan semprot diduga hanya dapat menginduksi ketahanan sistemik seperti yang ditunjukkan oleh perlakuan ekstrak pegagan, sirsak, sambiloto, meniran, patah tulang, dan kunyit putih (Tabel 1, Perlakuan semprot). Perlakuan ekstrak tanaman yang menunjukkan secara nyata menghambat pembentukan LLN pada perlakuan pencampuran sap diduga mengandung substansi antivirus, kecuali perlakuan ekstrak patah tulang, meniran, kunyit putih, pegagan, sambiloto dan sirsak. Ekstrak kunyit menunjukkan LLN yang nyata lebih rendah dibandingkan kontrol pada kedua perlakuan, namun THR LLN pada kedua perlakuan terutama perlakuan pencampuran sap dibawah $50 \%$, sehingga tidak dipilih untuk diuji keefektifannya di rumah kaca.

Tabel 1. Pengaruh perlakuan ekstrak kasar tanaman terhadap jumlah lesio lokal nekrotik (LLN) dan tingkat hambatan relatif (THR) pada C. amaranticolor

\begin{tabular}{|c|c|c|c|c|}
\hline \multirow{2}{*}{ Perlakuan } & \multicolumn{2}{|c|}{ Perlakuan semprot } & \multicolumn{2}{|c|}{ Perlakuan pencampuran sap } \\
\hline & LLN & THR (\%) & LLN & THR (\%) \\
\hline Anyelir & $26,6 \pm 13,8$ ef & $50,2 \pm 12,6 \mathrm{bcd}$ & $7,0 \pm 3,4 a b$ & $82,0 \pm 14,1 d$ \\
\hline Bogenvil & $15,6 \pm 9,5$ bcde & $68,1 \pm 22,4 \mathrm{cde}$ & $4,8 \pm 5,5 \mathrm{ab}$ & $89,5 \pm 12,7 \mathrm{~d}$ \\
\hline Cemara kipas & $25,4 \pm 12,7 \mathrm{def}$ & $49,3 \pm 14,9 \mathrm{bcd}$ & $7,5 \pm 1,3 \mathrm{ab}$ & $84,5 \pm 5,7 d$ \\
\hline Geranium & $4,6 \pm 2,3 \mathrm{ab}$ & $90,2 \pm 6,8$ ef & $11,2 \pm 4,6 a b$ & $74,9 \pm 14,7 \mathrm{~cd}$ \\
\hline Jengger ayam & $3,2 \pm 2,6 a b$ & $93,4 \pm 5,8 \mathrm{ef}$ & $5,6 \pm 4,2 a b$ & $85,0 \pm 13,0 \mathrm{~d}$ \\
\hline Pagoda & $0,8 \pm 1,0 \mathrm{a}$ & $98,7 \pm 1,4 \mathrm{f}$ & $1,4 \pm 1,9 \mathrm{a}$ & $96,1 \pm 5,7 \mathrm{~d}$ \\
\hline Patah tulang & $6,7 \pm 2,3 a b$ & $83,6 \pm 10,1 \mathrm{ef}$ & $45,4 \pm 14,0 \mathrm{c}$ & $8,2 \pm 23,1 b$ \\
\hline Pukul empat & $0,0 \pm 0,0 \mathrm{a}$ & $100,0 \pm 0,0 \mathrm{f}$ & $1,4 \pm 2,2 \mathrm{a}$ & $97,4 \pm 3,5 d$ \\
\hline Jahe merah $^{\mathrm{a}}$ & $12,6 \pm 6,8 \mathrm{abcd}$ & $72,8 \pm 15,4$ def & $7,4 \pm 7,5 \mathrm{ab}$ & $80,6 \pm 25,0 \mathrm{~d}$ \\
\hline Jambu biji & $4,4 \pm 3,2 \mathrm{ab}$ & $89,6 \pm 8,5$ ef & $1,4 \pm 1,9 a$ & $96,2 \pm 5,1 d$ \\
\hline Kecubung & $3,4 \pm 3,2 \mathrm{ab}$ & $92,8 \pm 7,0$ ef & $9,2 \pm 2,8 \mathrm{ab}$ & $79,3 \pm 10,3 \mathrm{~d}$ \\
\hline Kunyit $^{\mathrm{a}}$ & $23,0 \pm 7,9 \mathrm{def}$ & $50,0 \pm 27,6 \mathrm{bcd}$ & $22,0 \pm 14,9 \mathrm{~b}$ & $49,1 \pm 41,7 \mathrm{c}$ \\
\hline Kunyit putih ${ }^{\mathrm{a}}$ & $20,8 \pm 13,6$ cdef & $51,5 \pm 40,4$ bcd & $47,6 \pm 19,7 \mathrm{c}$ & $5,4 \pm 30,2 \mathrm{~b}$ \\
\hline Kulit Manggis & $4,8 \pm 5,7 \mathrm{ab}$ & $86,5 \pm 18,5$ ef & $4,4 \pm 0,9 a b$ & $90,6 \pm 3,2 \mathrm{~d}$ \\
\hline Meniran & $4,7 \pm 3,8 \mathrm{ab}$ & $87,4 \pm 13,7 \mathrm{ef}$ & $77,0 \pm 23,9 d$ & $-56,9 \pm 36,7 \mathrm{a}$ \\
\hline Mimba & $6,8 \pm 2,8 \mathrm{ab}$ & $83,6 \pm 10,4 \mathrm{ef}$ & $3,6 \pm 3,3 \mathrm{ab}$ & $91,3 \pm 9,5 \mathrm{~d}$ \\
\hline Mrico kepyar & $32,6 \pm 1,9 \mathrm{f}$ & $27,3 \pm 29,9 b$ & $8,0 \pm 3,1 \mathrm{ab}$ & $81,6 \pm 11,1 \mathrm{~cd}$ \\
\hline Pegagan & $0,6 \pm 1,3 \mathrm{a}$ & $99,3 \pm 1,6 \mathrm{f}$ & $40,0 \pm 20,0 \mathrm{c}$ & $18,9 \pm 57,7 \mathrm{~b}$ \\
\hline Sambiloto & $4,2 \pm 1,1 \mathrm{ab}$ & $90,1 \pm 6,0$ ef & $47,4 \pm 23,8 \mathrm{c}$ & $11,4 \pm 9,6 b$ \\
\hline Sirsak & $1,4 \pm 3,1 \mathrm{ab}$ & $95,6 \pm 9,8 \mathrm{f}$ & $53,0 \pm 14,7 \mathrm{c}$ & $-9,8 \pm 32,3 b$ \\
\hline Tempuyung & $8,2 \pm 5,5 a b c$ & $79,7 \pm 16,6$ ef & $4,4 \pm 0,9 a b$ & $90,1 \pm 4,5 \mathrm{~d}$ \\
\hline Temulawak $^{\mathrm{a}}$ & $26,4 \pm 17,8$ ef & $44,9 \pm 30,4 \mathrm{bc}$ & $6,0 \pm 3,5 \mathrm{ab}$ & $86,8 \pm 10,5 \mathrm{~d}$ \\
\hline Kc Panjang Sakit & $52,8 \pm 24,9 \mathrm{~g}$ & $0,0 \pm 0,0 \mathrm{a}$ & $52,8 \pm 24,9 c$ & $0,0 \pm 0,0 \mathrm{~b}$ \\
\hline
\end{tabular}

Angka yang diikuti huruf yang berbeda pada lajur yang sama menunjukkan hasil berbeda nyata berdasarkan uji selang berganda Duncan $\alpha=0,05 .{ }^{\text {a }}$ Ekstrak rimpang. 
Berdasarkan THR LLN perlakuan pencampuran sap yang menunjukkan THR diatas 70\%, maka sebanyak 15 ekstrak tanaman yaitu anyelir, bogenvil, cemara kipas, jengger ayam, pagoda, pukul empat, geranium, jahe merah, jambu biji, kecubung, kulit manggis, mimba, mrico kepyar, tempuyung, dan temulawak dipilih untuk diuji keefektifannya dalam mengendalikan BCMV pada kacang panjang. Ekstrak tanaman yang dipilih untuk diuji keefektifannya dalam mengendalikan BCMV pada kacang panjang adalah yang menunjukkan secara nyata jumlah LLN yang terendah terutama pada perlakuan pencampuran sap dan juga jumlah LLN nyata lebih rendah pada perlakuan semprot jika dibandingkan kontrol tanpa perlakuan (Tabel 1).

\section{Pengaruh Ekstrak Tanaman terhadap Infeksi BCMV pada Tanaman Kacang Panjang}

Kejadian Penyakit. Perlakuan ekstrak tanaman mampu menekan kejadian penyakit lebih rendah dari pada kontrol terinfeksi BCMV tanpa perlakuan dengan kisaran $0-53,3 \%$. Namun perlakuan ekstrak tanaman geranium dan jahe merah menunjukkan kejadian penyakit sama dengan tanaman kacang panjang sakit tanpa perlakuan (100\%) (Tabel 2).
Periode Inkubasi. Tanaman yang diberi perlakuan ekstrak tanaman menunjukkan periode inkubasi cenderung lebih panjang dari tanaman kacang panjang sakit tanpa perlakuan (Tabel 2). Perlakuan ekstrak tanaman bogenvil, jengger ayam, dan pukul empat tidak menunjukkan adanya gejala sehingga tidak ada periode inkubasi.

Keparahan Penyakit. Perlakuan ekstrak tanaman nyata menurunkan keparahan penyakit dibandingkan kontrol terinfeksi BCMV tanpa perlakuan, kecuali perlakuan ekstrak tanaman geranium dan jahe merah. Keparahan penyakit terendah ditunjukkan oleh perlakuan ekstrak tanaman jengger ayam, bogenvil, dan pukul empat, walaupun secara statistik tidak berbeda nyata dengan keparahan penyakit perlakuan ekstrak tanaman pagoda, anyelir, cemara kipas, mrico kepyar, kecubung, jambu biji, dan tempuyung. Ekstrak kulit manggis dan temulawak nyata menurunkan keparahan penyakit dibandingkan tanaman kacang panjang sakit tanpa perlakuan, namun menunjukkan keparahan yang lebih tinggi dibandingkan perlakuan ekstrak lainnya (Tabel 3).

Gejala. Gejala yang muncul akibat infeksi BCMV pada tanaman perlakuan adalah bervariasi tergantung

Tabel 2. Pengaruh ekstrak kasar tanaman terhadap kejadian penyakit (KP) dan periode inkubasi BCMV pada kacang panjang

\begin{tabular}{lccc}
\hline Perlakuan & \multicolumn{2}{c}{$\mathrm{KP}(\mathrm{n} / \mathrm{N})^{1}(\%)$} & Periode inkubasi $\left(\mathrm{HSI}^{2}\right)$ \\
\hline Anyelir & $1 / 15$ & $(6,7 \%)$ & 8,0 \\
Bogenvil & $0 / 15$ & $(0,0 \%)$ & -3 \\
Cemara kipas & $1 / 15$ & $(6,7 \%)$ & 7,0 \\
Geranium & $15 / 15$ & $(100,0 \%)$ & 7,6 \\
Jengger ayam & $0 / 15$ & $(0,0 \%)$ & - \\
Pagoda & $1 / 15$ & $(6,7 \%)$ & 12,0 \\
Pukul empat & $0 / 15$ & $(0,0 \%)$ & - \\
Jambu biji & $2 / 15$ & $(13,3 \%)$ & 7,5 \\
Rimpang jahe merah & $15 / 15$ & $(100,0 \%)$ & 7,4 \\
Kecubung & $2 / 15$ & $(13,3 \%)$ & 8,5 \\
Kulit manggis & $5 / 15$ & $(33,3 \%)$ & 8,4 \\
Mimba & $2 / 15$ & $(13,3 \%)$ & 11,0 \\
Mrico kepyar & $1 / 15$ & $(6,7 \%)$ & 10,0 \\
Tempuyung & $2 / 15$ & $(13,3 \%)$ & 7,0 \\
Rimpang temulawak & $8 / 15$ & $(53,3 \%)$ & 8,5 \\
Kacang panjang sakit & $15 / 15$ & $(100,0 \%)$ & 7,5 \\
Kacang panjang sehat & $0 / 15$ & $(0,0 \%)$ & - \\
\hline
\end{tabular}

${ }^{1} \mathrm{n}$ : jumlah tanaman yang terinfeksi, $\mathrm{N}$ : jumlah tanaman yang diamati $(\mathrm{KP}=\mathrm{n} / \mathrm{N} \times 100 \%)$, dikonfirmasi dengan ELISA,${ }^{2}$ HSI: Hari setelah inokulasi, ${ }^{3}$ tidak ada gejala. 
Tabel 3. Pengaruh perlakuan ekstrak tanaman terhadap keparahan penyakit dan gejala pada kacang panjang

\begin{tabular}{lccc}
\hline Perlakuan & $\begin{array}{c}\text { Rata-rata skor } \\
\text { keparahan penyakit }\end{array}$ & $\begin{array}{c}\text { THR Keparahan } \\
\text { penyakit }(\%)\end{array}$ & Gejala \\
\hline Anyelir & $0,1 \pm 0,5 \mathrm{a}$ & $96,7 \pm 12,9 \mathrm{c}$ & $\mathrm{Pm}$ \\
Bogenvil & $0,0 \pm 0,0 \mathrm{a}$ & $100,0 \pm 0,0 \mathrm{c}$ & - \\
Cemara kipas & $0,2 \pm 0,8 \mathrm{a}$ & $95,0 \pm 19,4 \mathrm{c}$ & $\mathrm{Mr}$ \\
Geranium & $2,9 \pm 0,4 \mathrm{~d}$ & $0,0 \pm 0,0 \mathrm{a}$ & $\mathrm{Pb}, \mathrm{MS}, \mathrm{MB}, \mathrm{MD}$ \\
Jengger ayam & $0,0 \pm 0,0 \mathrm{a}$ & $100,0 \pm 0,0 \mathrm{c}$ & - \\
Pagoda & $0,1 \pm 0,3 \mathrm{a}$ & $98,3 \pm 6,5 \mathrm{c}$ & $\mathrm{K}$ \\
Pukul empat & $0,0 \pm 0,0 \mathrm{a}$ & $100,0 \pm 0,0 \mathrm{c}$ & - \\
Jambu biji & $0,4 \pm 1,1 \mathrm{ab}$ & $90,0 \pm 26,4 \mathrm{c}$ & $\mathrm{MR}, \mathrm{MS}$ \\
Rimpang jahe merah & $2,5 \pm 0,9 \mathrm{~d}$ & $10,0 \pm 12,7 \mathrm{a}$ & $\mathrm{Pb}, \mathrm{MS}, \mathrm{MB}, \mathrm{MD}$ \\
Kecubung & $0,3 \pm 0,9 \mathrm{a}$ & $88,9 \pm 30,0 \mathrm{c}$ & $\mathrm{Pm}, \mathrm{MS}$ \\
Kulit manggis & $1,1 \pm 1,5 \mathrm{bc}$ & $70,0 \pm 44,5 \mathrm{~b}$ & $\mathrm{~K}, \mathrm{Pm}, \mathrm{MS}$ \\
Mimba & $0,4 \pm 1,1 \mathrm{ab}$ & $90,0 \pm 26,4 \mathrm{c}$ & $\mathrm{MR}, \mathrm{MS}$ \\
Mrico kepyar & $0,2 \pm 0,8 \mathrm{a}$ & $95,0 \pm 19,4 \mathrm{c}$ & $\mathrm{MR}$ \\
Tempuyung & $0,4 \pm 1,1 \mathrm{ab}$ & $90,0 \pm 26,4 \mathrm{c}$ & $\mathrm{Pm}, \mathrm{MS}$ \\
Rimpang temulawak & $1,7 \pm 1,6 \mathrm{c}$ & $55,0 \pm 44,5 \mathrm{~b}$ & Pm, MR, MS \\
Kacang Panjang sakit & $2,9 \pm 0,4 \mathrm{~d}$ & $0,0 \pm 0,0 \mathrm{a}$ & $\mathrm{Pb}, \mathrm{MS}, \mathrm{MB}, \mathrm{MD}$ \\
Kacang Panjang sehat & $0,0 \pm 0,0 \mathrm{a}$ & $100,0 \pm 0,0 \mathrm{c}$ & - \\
\hline
\end{tabular}

Angka yang diikuti huruf yang berbeda pada lajur yang sama menunjukkan hasil berbeda nyata berdasarkan uji selang berganda Duncan $\alpha=0,05, \mathrm{~K}=$ klorosis, $\mathrm{MR}=$ mosaik ringan, $\mathrm{MS}=$ mosaik sedang, $\mathrm{MB}=$ mosaik berat, $\mathrm{MD}=$ malformasi daun, $\mathrm{Pb}=$ penebalan tulang daun, $\mathrm{Pm}=$ pemucatan tulang daun, dan $-=$ tidak ada gejala .
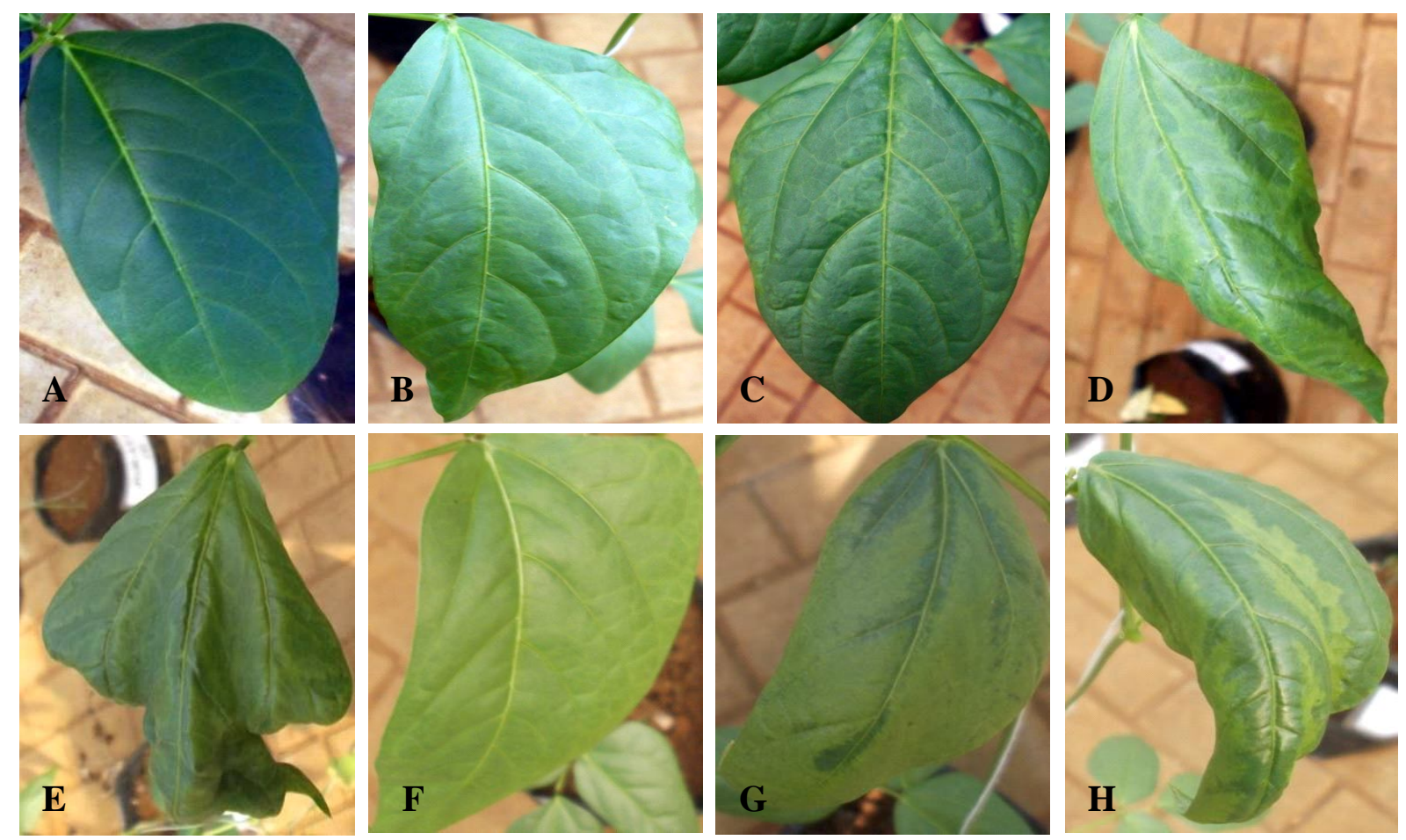

Gambar 1. Gejala daun kacang panjang terinfeksi BCMV (B-H) dan daun sehat (A). Skor keparahan penyakit berdasarkan gejala visual. (A) Skor 0; sehat, (B) skor 1; mosaik ringan disertai pemucatan tulang daun, (C) Skor 2: mosaik sedang, (D) Skor 3: mosaik berat, (E) Skor 4: mosaik berat disertai malformasi daun yang parah, $(\mathrm{F})$ Klorosis, $(\mathrm{G}-\mathrm{H})$ Klorosis dengan penebalan tulang daun. 
perlakuan ekstrak tanaman dan keparahan penyakit (Tabel 3). Gejala yang dapat dilihat mulai dari mosaik ringan dengan pemucatan tulang daun (vein clearing), mosaik sedang, mosaik berat dengan atau tanpa malformasi daun, klorosis, dan penebalan tulang daun (vein banding) (Gambar 1b-h). Tanaman perlakuan ekstrak geranium, jahe merah, dan tanaman kacang panjang sakit tanpa perlakuan menunjukkan gejala penebalan tulang daun, mosaik sedang sampai berat yang disertai malformasi daun (Gambar 1c-d dan 1g-h). Sedangkan tanaman perlakuan lainnya menunjukkan gejala yang lebih ringan berupa klorosis, pemucatan tulang daun, mosaik ringan hingga mosaik sedang (Gambar 1.b, c, f). Hanya tanaman yang diberi perlakuan ekstrak daun jengger ayam, bogenvil, dan pukul empat yang tidak menunjukkan adanya gejala (Tabel 3 ).

Titer BCMV. Pada perlakuan ekstrak tanaman bogenvil, pukul empat, dan jengger ayam tidak terdeteksi BCMV. Hal ini mengonfirmasi ketiadaan kejadian dan keparahan penyakit. Sedangkan perlakuan lainnya positif terdeteksi BCMV, namun NAE nyata lebih rendah dibandingkan dengan tanaman kacang panjang sakit tanpa perlakuan, kecuali perlakuan ekstrak mimba, kulit manggis, jahe merah, temulawak, dan geranium (Tabel 4).
THR Titer Virus. Perlakuan ekstrak tanaman mampu menghambat titer BCMV bila dibandingkan dengan kontrol terinfeksi BCMV tanpa perlakuan (kacang panjang sakit), kecuali perlakuan ekstrak tanaman mimba, kulit manggis, jahe merah, temulawak, dan geranium yang tidak berbeda nyata THRnya dengan kontrol (kacang panjang sakit). THR titer BCMV yang ditunjukkan oleh perlakuan ekstrak tanaman bogenvil, pukul empat dan jengger ayam paling tinggi (100\%) dibandingkan perlakuan lainnya (Tabel 4).

Semua ekstrak tanaman yang diuji memiliki kemampuan dalam menekan BCMV pada $C$. amaranticolor pada perlakuan semprot, namun tidak demikian pada perlakuan pencampuran sap. Perlakuan pencampuran sap ekstrak patah tulang, kunyit putih, meniran, pegagan, sambiloto dan sirsak tidak mampu menekan LLN seperti perlakuan lainnya. Kedua cara aplikasi ekstrak tanaman dapat dimanfaatkan dengan mudah dalam seleksi ekstrak tanaman, mikroba non patogenik, atau agens hayati lainnya untuk mendapatkan agens yang bersifat sebagai penginduksi ketahanan sistemik ataupun yang mengandung aktivitas antivirus.

Lima belas ekstrak tanaman hasil seleksi menunjukkan konsistensi dalam menekan BCMV pada kacang panjang, kecuali ekstrak daun geranium dan jahe

Tabel 4. Pengaruh perlakuan ekstrak kasar tanaman terhadap nilai absorbansi ELISA (NAE)

\begin{tabular}{lccr}
\hline Perlakuan & NAE & Keterangan & THR virus $(\%)$ \\
\hline Anyelir & $0,673 \pm 1,127 \mathrm{ab}$ & + & $81,0 \pm 42,4 \mathrm{~cd}$ \\
Bogenvil & $0,160 \pm 0,008 \mathrm{a}$ & - & $100,0 \pm 0,0 \mathrm{~d}$ \\
Cemara kipas & $0,595 \pm 1,029 \mathrm{ab}$ & + & $82,8 \pm 38,4 \mathrm{~cd}$ \\
Geranium & $2,875 \pm 0,066 \mathrm{e}$ & + & $-4,0 \pm 3,0 \mathrm{a}$ \\
Jengger ayam & $0,173 \pm 0,009 \mathrm{a}$ & - & $100,0 \pm 0,0 \mathrm{~d}$ \\
Pagoda & $0,670 \pm 1,126 \mathrm{ab}$ & + & $80,7 \pm 43,1 \mathrm{~cd}$ \\
Pukul empat & $0,167 \pm 0,008 \mathrm{a}$ & - & $100,0 \pm 0,0 \mathrm{~d}$ \\
Jambu biji & $0,748 \pm 1,286 \mathrm{ab}$ & + & $78,5 \pm 48,1 \mathrm{~cd}$ \\
Rimpang jahe merah & $2,455 \pm 0,311 \mathrm{cde}$ & + & $4,1 \pm 10,0 \mathrm{ab}$ \\
Kecubung & $0,631 \pm 1,059 \mathrm{ab}$ & + & $81,5 \pm 41,3 \mathrm{~cd}$ \\
Kulit manggis & $1,447 \pm 1,301 \mathrm{abcd}$ & + & $50,3 \pm 49,0 \mathrm{bcd}$ \\
Mimba & $1,742 \pm 1,443 \mathrm{bcde}$ & + & $39,1 \pm 55,7 \mathrm{abc}$ \\
Mrico kepyar & $1,104 \pm 1,299 \mathrm{ab}$ & + & $63,8 \pm 49,6 \mathrm{~cd}$ \\
Tempuyung & $1,222 \pm 1,448 \mathrm{abc}$ & + & $59,5 \pm 55,4 \mathrm{~cd}$ \\
Rimpang temulawak & $2,667 \pm 0,294 \mathrm{de}$ & + & $3,4 \pm 12,1 \mathrm{ab}$ \\
Kacang panjang sakit & $2,764 \pm 0,049 \mathrm{e}$ & + & $0,0 \pm 0,0 \mathrm{ab}$ \\
Kacang panjang sehat & $0,194 \pm 0,014 \mathrm{a}$ & - & $100,0 \pm 0,0 \mathrm{~d}$ \\
\hline Ana & + & + & +
\end{tabular}

Angka yang diikuti huruf yang berbeda pada lajur yang sama menunjukkan hasil berbeda nyata berdasarkan uji selang berganda Duncan $\alpha=0,05$. NAE Kontrol negatif ELISA: 0,182, NAE kontrol positif ELISA: 3,083. Uji dinyatakan positif jika NAE sampel dua kali NAE kontrol negatif ELISA (positif jika NAE $\geq 0,364$ ). 
merah. Geranium (Pelargonium pratense) dilaporkan memiliki senyawa flavonoid dan polifenol yang memiliki efek antivirus terhadap infeksi TMV pada kultivar sensitif Cucurbitacea (Orazov \& Nikitana, 2004), tetapi tidak demikian terhadap BCMV. Hal ini menunjukkan bahwa efek antivirus geranium tergantung pada spesies virus dan spesies tanaman (penelitian ini menggunakan Pelargonium odoranthisimum).

Ekstrak tanaman jengger ayam, bogenvil, pukul empat, pagoda, anyelir, cemara kipas, mrico kepyar, kecubung, jambu biji, dan tempuyung secara nyata mampu menekan BCMV. Kandungan bouganin pada bogenvil, Mirabilis Antiviral Protein (MAP) pada bunga pukul empat serta Celosia cristata protein (CCP) pada jengger ayam diduga bersifat antivirus (Habuka et al., 1991; Bolognesi et al., 1997; Balasubrahmanyam et al., 2000). Namun protein antivirus pada ekstrak tanaman lainnya belum diketahui. Mekanisme penekanan virus tumbuhan oleh ekstrak tanaman, tidak hanya karena induksi ketahanan dan kandungan protein antivirus. Tetapi dapat karena kandungan senyawa aktif dalam tanaman seperti flavonoid, terpenoid, coumarin, tanin, quercetin, saponin dan fenol. Menurut Jassim \& Naji (2003), senyawa flavonoid dan caumarin bekerja menghalangi sintesis RNA, senyawa terpenoid dan saponin menghambat sintesis DNA, senyawa tannin dan fenol menghambat replikasi RNA dan DNA virus, sedangkan quercetin mampu menghambat enzim transkriptase dan polimerase. Flavonoid dilaporkan mengganggu interaksi protein selubung dan reseptor inang yang penting dalam replikasi Potato virus $X$ dan Tomato bushy stunt virus (French \& Towers, 1992; Rusak et al., 1997). Oleh karena itu perlu diteliti lebih lanjut mekanisme penekanan BCMV oleh ekstrak tanaman potensial yang didapatkan dalam penelitian ini.

\section{SIMPULAN}

Seleksi ekstrak tanaman pada C. amaranticolor menunjukkan semua ekstrak yang diuji mampu menekan lesiolokal nekrotik (LLN) secara nyata melalui cara semprot dan pencampuran sap, kecuali perlakuan ekstrak patah tulang, meniran, kunyit, kunyit putih, pegagan, sambiloto dan sirsak yang tidak mampu menekan LLN pada perlakuan pencampuran sap. Efikasi lima belas ekstrak tanaman dalam menekan BCMV pada kacang panjang di rumah kaca menunjukkan sebelas ekstrak tanaman diantaranya (jengger ayam, bogenvil, pukul empat, pagoda, anyelir, cemara kipas, mrico kepyar, kecubung, jambu biji, dan tempuyung) efektif menekan keparahan dan titer BCMV dibandingkan tanaman kacang panjang sakit tanpa perlakuan. Diantara ekstrak yang diuji ekstrak tanaman bogenvil, pukul empat, dan jengger ayam paling efektif mengeliminasi BCMV.

\section{SANWACANA}

Penelitian ini terlaksana atas dana Penelitian Unggulan Strategis Nasional Dirjen DIKTI yang telah diberikan kepada penulis melalui DIPA IPB dengan SPK No. 5/IT3.41.2/LI/SPK/2013. Terima kasih kepada Dita Megasari S.P., Nicko Surya S.P. dan Edi Supardi atas bantuannya selama penelitian.

\section{DAFTAR PUSTAKA}

[BPS] Badan Pusat Statistik. 2012. Produksi sayuran di Indonesia. Jakarta (ID): Badan Pusat Statistik. Tersedia pada: http://www.bps.go.id / tab_sub/view.php.diunduh 20 Nopember 2012.

Balasaraswathi R, Sadasivam S, Ward M, \& Walker JM. 1998. An antiviral protein from Bougainvillea spectabilis roots, purification and characterization. Phytochemistry 47(8): 15611565.

Balasubrahmanyam A, Baranwal VK, Lodha ML, Varma A, \& Kapoor HC. 2000. Purificarion and properties of growth stage-dependent antiviral proteins from the leaves of Celosia cristata. Plant Sci.154(1): 13-21.

Bolognesi A, Polito L, Olivieri F, Valbonesi P, Barbieri L, Battelli MG, Carussi MV, Benvenuto E, Del Vechio Blanco F, Di Maro A, Parente A. Di Loreto \& M. Stirpe F. 1997. New ribosome inactivating proteins with polynucleotide: adenosine glycosidase and antiviral activities from Basella rubra L. and Bougainvillea spectabilis Willd. Planta 203(4): 422-429.

Damayanti TA, Alabi OJ, Naidu RA, \& Rauf A. 2009. Severe outbreak of a yellow mosaic disease on the yard long bean in Bogor, West Java. Hayati J. Biosci.16(2): 78-82.

Deepthi N, Madhusudhan KN, Udayashankar AC, Kumar HB, Prakash HS, \& Shetty HS. 2007. Effect of plant extracts and acetone precipitated proteins from six medicinal plants against tobamovirus infection. Int. J. Virol. 3(2): 8087. 
Duriat AS. 2008. Pengaruh ekstrak bahan nabati dalam menginduksi ketahanan cabai terhadap vektor dan penyakit keriting kuning. J. Hortikultura 18(4): 446-456.

French CJ \& Towers GHN. 1992. Inhibition of infectivity of Potato virus $\mathrm{X}$ by flavonoids. Phytochemistry 31(9): 3017-3020.

Habuka N, Miyano M, Kataoka J, \& Noma M. 1991. Escherichia coli ribosome is inactivated by Mirabilis antiviral protein which cleaves the Nglycosidic bond at A2660 of $23 \mathrm{~S}$ ribosomal RNA. J. Mol. Biol. 221(3): 737-743.

Hersanti. 2004. Pengaruh Ekstrak Beberapa Tumbuhan dalam Menginduksi Ketahanan Sistemik Tanaman Cabai Merah (Capsicum annuum L. ) terhadap Cucumber Mosaic Virus (CMV). Disertasi. Sekolah Pascasarjana. Universitas Padjadjaran, Bandung.

Jassim SAA \& Naji MA. 2003. Novel antiviral agents: a medicinal plant perspective. J. Appl. Microbiol. 95(3): 412-427.

Kubo S, Ikeda T, Imaizumi S, Takanami Y, \& Mikami Y. 1990. A potent plant virus inhibitor found in Mirabilis jalapa L. Ann. Phytopath. Soc. Japan 56(4): 481-487.

Kurnianingsih L \& Damayanti TA. 2012. Lima ekstrak tumbuhan untuk menekan infeksi Bean common mosaic virus pada tanaman kacang panjang. $J$. Fitopatol. Indones. 8(6): 155-160.

Madhusudhan KN, Vinayarani G, Deepak SA, Niranjana SR, Prakash HS, Singh GP, Sinha AK, \& Prased BC. 2011. Antiviral activity of plant extracts and other inducers against Tobamoviruses infection in bell pepper and tomato plants. Int. J. Plant Pathol. 2(1): 35-42

Mahdy AMM, Hafez MA, EL-Dougdoug KhA, Fawzy RN, \& Shahwan ESM. 2010. Effect of two biotic inducers on salicylic acid induction in tomato infected with Cucumber mosaic cucumovirus. Egyptian J. Virol. Suplemen: 352-372.
Orazov OE \& Nikitina VS. 2004. Phenolic compounds from some species of Geranium $\mathrm{L}$ as an immunostimulant antiviral agent at Cucurbitaceae cultures. In: Sadatinejad S, Mohammadi S, Soltani A, Ranjbar A, (Eds.) Proceedings of The Fourth International Iran \& Russia Conference in Agriculture and Natural Resources Pp 282-284 [Internet]. Tersedia pada: http://iirc.narod.ru/ 4conference/Fullpaper/10072.pdf

Rajesh S, Balasaraswathi R, Doraisamy S, \& Sadasivam S. 2005. Synthesis and cloning of cDNA encoding an antiviral protein from the leaves of Bougainvillea spectabilis Willd. (Nyctaginaceae). World J. Agric. Sci.1(2): 101104.

Rusak G, Krajacic M, \& Plese N. 1997. Inhibition of Tomato bushy stunt virus infection using a quercetagetin flavonoid isolated from Centaurea rupestris L. Antiviral Res. 36(2): 125-129.

Setyastuti L. 2008. Tingkat Ketahanan Sembilan Kultivar Kacang Panjang Terhadap Infeksi Bean common mosaic virus (BCMV). [Skripsi]. Fakultas Pertanian, Institut Pertanian Bogor.

Susetio H. 2011. Penyakit Mosaik Kuning Kacang Panjang: Respons Varietas Kacang Panjang (Vigna sinensis L.) dan Efisiensi Penularan melalui Kutudaun (Aphis craccivora Koch.). Skripsi. Fakultas Pertanian, Institut Pertanian Bogor.

Udayashankar AC, Nayaka SC, Kumar HB, Mortensen CN, Shetty HS, \& Prakash HS. 2010. Establishing inoculum threshold levels for Bean common mosaic virus strain Blackeye cowpea mosaic infection in cowpea seed. African J. Biotech. 9 (53): 8958-8969.

Verma HN, Baranwal VK, \& Srivastava S. 1998. Antiviral substances of plant origin. In: Hadidi A, Khetarpal RK, Koganezawa H, eds. Plant Viruses Diseases Control. Pp 154-162. APS Press, St. Paul (US):

Vivanco JM, Querci M, \& Salazar LF. 1999. Antiviral and antiviroid activity of MAP-containing extracts from Mirabilis jalapa roots. Plant Dis. 83(12): 1116-1121. 